\title{
Implementasi Pendidikan Karakter di Pondok Pesantren An- Nurîyah Bonto Cini' Kabupaten Jeneponto Provinsi Sulawesi Selatan
}

\author{
Haeruddin, Bahaking Rama, Wahyuddin Naro
}

\author{
Universitas Islam Negeri (UIN) Alauddin Makassar, Indonesia \\ Jl. H. M Yasin Limpo No. 36 Samata-Gowa, Tlp. 0411-1500365, Kode Pos 92114 \\ Email: haerulhaeruddin94@gmail.com, bahaking.rama@yahoo.co.id, \\ wahyuddin.naro@yahoo.co.id
}

\begin{abstract}
This study presents a problem ebout character education at Pondok Pesantren An-Nurîyah Bonto Cini' Kabupaten Jeneponto, Provinsi Sulawesi Selatan. The purpose of this study is to find out how the implementation of character education. The research method used is descriptive qualitative that is to reveal facts, data, and phenomena that occur in the field. The results of this study indicate that: 1) Character Education in Pondok Pesantren An-Nurîyah Bonto Cini' can be implemented through learning activities, extracurricular activities, and religious activities, 2) Factors supporting the implementation of character education are the existence of adequate facilities and infrastructure in the learning process. The inhibiting factors for character education are non-conducive internal and external factors, 3) The description of the character of the santri, which is that there are no santri who violate significantly. The conclusion is, that the learning process, extracurricular activities, and religious values, are very effective and efficient for all elements in the Islamic boarding school, so that character education appears in the santri. Thus it is necessary to maximize the implementation of character education to all elements in Islamic boarding schools in order to create a generation with character, integrity, and excellence.
\end{abstract}

\section{Keywords: Character Education, Religious Value, Islamic Boarding School}

Abstrak: Penelitian ini menyajikan masalah tentang pendidikan karakter di Pondok Pesantren An-Nurîyah Bonto Cini' Kabupaten Jeneponto, Provinsi Sulawesi Selatan. Tujuan penelitian ini untuk mengetahui bagaimana implementasi pendidikan karakter. Metode penelitian yang digunakan adalah kualitatif deskriptif yaitu untuk mengungkap fakta, data, dan fenomena yang terjadi dilapangan. Hasil penelitian ini menunjukkan bahwa: 1) Pendidikan Karakter di Pondok Pesantren An-Nurîyah Bonto Cini' dapat diimplementasikan melalui kegiatan pembelajaran, kegiatan ekstrakurikuler, dan aktifitas religius, 2) Faktor pendukung pelaksanaan pendidikan karakter yaitu adanya sarana dan prasarana yang memadai pada proses pembelajaran. Faktor penghambat pelaksanaan pendidikan karakter yaitu faktor internal dan eksternal yang tidak kondusif, 3) Gambaran karakter santri yaitu tidak ada santri yang melanggar secara signifikan. Kesimpulan yaitu, bahwa proses pembelajaran, kegiatan ekstrakurikuler, dan nilai religius, sangat efektif dan efesien kepada seluruh elemen yang ada di pondok pesantren, sehingga pendidikan karakter nampak pada diri santri. Dengan demikian perlu dimaksimalkan lagi implementasi pendidikan karakter kepada seluruh elemen yang ada di pondok pesantren agar dapat menciptakan generasi yang berkarakter, berintegritas, dan tetap unggul.

Kata Kunci: Pendidikan Karakter, Nilai Relegius, Pesantren

Jurnal Pendidikan Agama Islam Al-Thariqah Vol. 4, No. 1, Januari - Juni 2019

Received: 27 May 2019; Accepted: 07 July 2019; Published: 09 July 2019

*Corresponding Author: haerulhaeruddin94@gmail.com 


\section{PENDAHULUAN}

Aspek pendidikan di Indonesia yang terkait tentang pendidikan karakter, masih banyak masyarakat yang kurang memahami, menghayati, meyakini, dan mengamalkannya dengan baik, sedangkan karakter dapat diartikan sebagai tabiat, kejujuran, kepribadian, kewibawaan, motivasi, keterampilan, kejiwaan, sikap, dan watak (Kamus Pusat Bahasa, 2014: 202). Sedangkan pendidikan karakter adalah upaya pembentukan dan pembinaan keperibadian yang baik pada diri anak untuk membentuk kebiasaan-kebiasaan baik dalam kehidupan berakhlak mulia. (Haedar, 2013: 93). Sebagaimana firman Allah swt., dalam Q.S. al-Ahzab/33: 21.

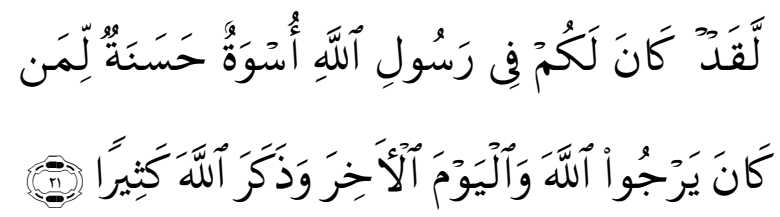

"Sesungguhnya telah ada pada diri Rasulullah itu suri teladan yang baik bagimu yaitu bagi orang yang mengharap rahmat Allah dan kedatangan hari kiamat dan dia banyak menyebut nama Allah".

Menurut Quraish Shihab (2009: 102) keteladanan adalah perilaku seseorang yang patut dilteladani karena perilaku dan perbuataannya tergambarkan akhlak mulia (akhlâk alkarîmah), atau nilai-nilai karakter yang baik yang dinampakkan pada diri Rasulullah saw. Akan tetapi perilaku dan perbuatan inilah yang hilang di zaman sekarang, akhlak mulia berubah jadi akhlah memalukan, ketuhan yang Maha Esa, berubah menjadi keuangan yang maha kuasa, sehingga nilai-nilai keimanan dan ketakwaan sebahagian besar tak nampak lagi ditengah-tengah masyarakat yang berpendidikan, baik dari latar belakang pendidikan Islam maupun yang dari latar belakang pendidikan umum.

Berkaitan dengan latar belakang pendidikan karakter di Indonesia tersebut, Pusat Kurikulum Badan Penelitan dan Pengembangan Kementerian Pendidikan Nasional dalam publikasinya berjudul Pedoman Pelaksanaan Pendidikan Karakter tahun 2011, pendidikan karakter pada intinya bertujuan membentuk bangsa yang tangguh, kompetitif, berakhlak mulia, bermoral, bertoleran, bergotong royong, berjiwa patriotik, berkembang dinamis, berorientasi ilmu pengetahuan dan teknologi, yang semuanya dijiwai oleh iman dan takwa kepada Tuhan Yang Maha Esa berdasarkan Pancasila. Pedomen ini pun sudah tidak dipadang lagi oleh sebahagian masyarakat yang ada di Indonesia.

Berdasarkan latar belakang tersebut dan observasi di lapangan, penulis mengamati secara langsung tentang pendidikan karakter yang diimplementasikan di Pondok Pesantren An-Nurîyah Bonto Cini, Kabupaten Jeneponto, Provinsi Sulawesi Selatan, apakah sudah sesuai dengan tujuan Pedoman Pelaksanaan Pendidikan Karakter tahun 2011, sehingga dapat difokuskan pada penelitian ini tentang pendidikan karakter. Adapun yang dirumuskan yaitu: 1) Bagaimana implementasi pendidikan karakter di Pondok Pasantren An-Nurîyah Bonto Cini', Kabupaten Jeneponto, Provinsi Sulawesi Selatan? 2) Apakah faktor pendukung dan penghambat pada implementasi pendidikan karakter di Pondok Pesantren An-Nurîyah Bonto Cini', Kabupaten Jeneponto, Provinsi Sulawesi Selatan? 3) Bagaimana gambaran karakter santri di Pondok Pesantren An-Nurîyah Bonto Cini', Kabupaten Jeneponto, Provinsi Sulawesi Selatan?

\section{KONSEP TEORI}

Pendidikan karakter menjadi semakin mendesak untuk diterapkan dalam lembaga pendidikan, mengingat dari berbagai macam perilaku yang non- 
edukatif kini telah memasuki lembaga pendidikan Islam dan umum, sebagaimana hasil penelitian Megawangi tentang ketidak jujuran peserta didik di Sekolah Menengah Kejuruan-Teknik Informatika (SMK-TI) di Bogor, dimana hampir $81 \%$ peserta didiknya sering membohongi orang tua $30,6 \%$ sering memalsukan tanda tangan orang tua/wali, $13 \%$ peserta didik sering mencuri, dan $11 \%$ peserta didik sering memeras orang tuanya. (Tanshzil, 2012: 2).

Menurut Bahaking Rama (2010: 9) dalam bukunya yang berjudul Jejak Pembaharuan Pendidikan Pesantren; Kajian Pesantren As'adîyah Sengkang Sulawesi Selatan, pada tahun 2003 bahwa, sistem pendidikan pesantren memiliki banyak perubahan maka dari sinilah diperlukan adanya penelitian yang lebih condong pada penelitian pendidikan karakter di pondok pesantren. Muljono Damopolii (2011: 21) dalam disertasinya yang berjudul Pesantren Modern IMMIM Pencetak Muslim Modern mengatakan bahwa, pola pembaharuan perlu di aplikasikan karakter keimanan dan ketakwaan dalam kehidupan sehari-hari, dengan maksud dan tujuan agar manusia dapat mencapai standarnisasi sebagai insan kâmil (Amiruddin, 2010: 13).

Pondok Pesantren dapat disebut sebagai lembaga jika memuat lima indikator Pesantren yaitu: 1) Kiai, 2) santri, 3) asrama, 4) masjid, dan 5) pengajaran ilmu-ilmu yang berisi ajaranajaran Islam. (Hurairah, 2009: 82). Ciri yang paling khas dari pendidikan di pesantren yaitu adanya pengajian kitab kuning. (Yaumi, 2014: 9). Kegiatan ini berupa penyampaian materi kitab yang dikaji oleh seorang Kiai kepada para santrinya. Menurut Nurcholis Madjid ternyata dalam pengajian ini, segi kognitifnya tidak cukup diberi tekanan, terbukti dengan tidak adanya sistem kontrol berupa test atau ujian-ujian terhadap penguasaan santri pada bahan pelajaran yang diterimanya sehingga para santri kurang diberi kesempatan menyampaikan ide-idenya apalagi untuk mengajukan kritik bila menemukan kekeliruan dalam pelajaran sehingga daya nalar dan kreatifitas berpikir mereka agak terhambat (Yasmadi, 2009: 23). Imam Bawani (2009: 99) merumuskan beberapa poin mengenai ciri-ciri pendidikan di pesantren, yakni: a) Adanya hubungan yang akrab antara santri dengan Kiai, b) Taatnya santri kepada Kiai, c) Hidup hemat dan sederhana benar-benar dilakukan dalam lingkungan pesantren, d) Semangat menolong diri sendiri amat terasa karena seluruh pekerjaan dilakukan secara mandiri, dan e) Jiwa tolong menolong atau persaudaraan sangat mewarnai pergaulan di pesantren.

Menurut Babun Suharto (2011: 19) pesantren dapat dikelompokkan menjadi lima yaitu: 1) Pesantren salaf/klasik, dengan sistem pendidikan salaf dan dipadukan dengan sistem klasikal, 2) Pesantren semi berkembang, dengan perpaduan sistem pendidikan klasik dan klasikal dengan kurikulum 90\% agama, dan 10\% umum, 3) Pesantren berkembang, dengan variasi kurikulum yakni 70\% agama, dan 30\% umum, 4) Pesantren khalaf/modern, yakni Pesantren dengan sistem pendidikan yang lebih lengkap, terhadap pendidikan formal (umum) dengan penambahan diniyah, perguruan tinggi baik umum maupun agama, penekanan dua bahasa baik Arab maupun Inggris dan dilengkapi dengan koperasi Pesantren, 5) Pesantren ideal, sebagai bentuk Pesantren modern dengan lembaga pendidikan lebih lengkap terutama dengan bidang keterampilan seperti: pertanian, perikanan, tehnik, perbankan, dan memperhatikan kualitas dengan tidak meninggalkan ciri khas Pesantren yang relevan dengan kebutuhan masyarakat. 


\section{METODE PENELITIAN}

Jenis penelitian ini adalah deskriptif kualitatif, karena penelitian ini memberikan gambaran tentang hasil penelitian dengan mendeskripsikan datadata aktual yang diperoleh di lapangan (Sukmadinata, 2009: 60). Penelitian ini mendeskripsikan tentang pendidikan karakter di Pondok Pesantren An-Nurîyah Bonto Cini', Kabupaten Jeneponto, Provinsi Sulawesi Selatan. Tempat penelitian yaitu di Pondok Pesantren AnNurîyah Bonto Cini', Dusun Bonto Cini', Desa Maccini Baji, Kecamatan Batang, Kabupaten Jeneponto, Provinsi Sulawesi Selatan.

Pendekatan yang digunakan pada penelitian ini adalah pendekatan multidisipliner yaitu pendekatan yang berkaitan dengan berbagai ilmu sosiologis dan psikologis serta pendekatan penelitian fenomenologik. Data pada penelitian ini dikelompokkan menjadi dua macam, yaitu: pertama, data primer adalah data yang diperoleh tanpa melalui orang kedua data tersebut asli dari informan yang bersangkutan secara langsung. Kedua, data sekunder yaitu data yang diperoleh melalui file-file yang masih bersifat mentah dimana data tersebut masih perlu untuk di tinjau kembali untuk memastikan letak atau tempat penelitian itu sendiri.

Metode pengumpulan data yang digunakan pada penelitian ini yaitu: mengobservasi situasi dankondisi yang nampak di lapangan peneltian, wawancara dilakukan untuk mendapatkan data-data yang konkrit yang bersangkutan tentang fokus penelitian, dan dokumentasi, hal ini dapat menguatkan data-data yang paparkan sebelumnya. Sedangkan instrumen penelitian yang digunakan adalah: pedoman observasi, pedoman wawacara, dan dokumentasi.

Penggunaan teknik analisis data adalah: 1) Reduksi data; 2) Penyajian data; dan 3) Penarikan kesimpulan.
Pengujian keabsahan data pada penelitian ini didasarkan kriteria, yaitu; Derajat credibility, transferability, dependebelity dan confirmability (Sugiyono, 2013: 75).

\section{HASIL DAN PEMBAHASAN}

\section{Hasil Penelitian}

\section{Implementasi Pendidikan Karakter di Pondok Pesantren An-Nurîyah Bonto Cini' Kabupaten Jeneponto Provinsi Sulawesi Selatan.}

Implementasi Pendidikan Karakter di Pondok Pesantren An-Nurîyah Bonto Cini' Kabupaten Jeneponto Provinsi Sulawesi Selatan memiliki beberapa kegiatan, yaitu: Pengaplikasian pendidikan karakter di Pondok Pesantren An-Nurîyah Bonto Cini' khususnya dalam kegiatan proses pembelajaran di dalam kelas, dilaksanakan secara integrasi melalui jadwal mata pelajaran yang ada dengan cara mengefesienkan aktifitas pembelajaran santri dengan mengembangkan tiga rana yaitu: rana kognitif, rana afektif, dan rana psikomotorik.

Implementasi pendidikan karakter melalui kegiatan religius di Pondok Pesantren An-Nurîyah Bonto Cini' Kabupaten Jeneponto, dapat diselenggarakan dengan baik karena pengawasan yang ketat dan kesadaran santri itu sendiri untuk tetap semangat mengikuti seluruh rangkaian kegiatan yang ada di dalam Pondok Pesantren AnNurîyah Bonto Cini' Kabupaten Jeneponto yaitu: a) Kegiatan harian ini, adalah kegiatan yang sudah melekat pada diri santri seperti kegiatan menghafal, pengajian kitab kuning, thakâssûs, setor hafalan tentunya proses pembelajaran yang di lakukan di dalam kelas, makan tidur dan lain-lain sebagainya, b) Kegiatan setiap satu pekan ini, sudah menjadi tradisi santri dan santriwati seperti kegiatan bela diri dilaksanakan pada hari jumat sore, pada malam harinya digunakan untuk kegiatan thakâssûs yang dibina langsung oleh ustadz dan ustazah, 
c) Kegiatan setiap bulan ini, dimana setiap eleman yang ada di pondok pesantren tersebut mengadakan rapat komite, Kegiatan ini dipimpiin langsung oleh Pimpinan Pondok Pesantren AnNuriyah Bonto Cini' Kabupaten, d) Kegiatan tahunan di Pondok Pesantren An-Nuriyah Bonto Cini' Kabupaten Jeneponto adalah mengadakan kegiatan reuni setiap angkatan, melaksanakan mauilid atau memperingati hari lahirnya Nabi Muhammad saw., kegiatan persiapan memasuki bulan suci Ramadhan yaitu buka bersama dan kegiatan safari ramadhan dan kegiatan penamatan santri.

Upaya lainnya yang dilakukan ustadz/ustadzah dalam pembentukan akhlatul karîmah santri adalah trening dakwah, agar santri senatiasa meningkakan kualitas ilmu dakwahnya di masyarakat dan selalu taat kepada Allah swt, sabar dan ikhlas dalam menjalankan tanggung jawabnya sebagai pendidik, sehingga nampaklah karakter santri terhadap Tuhan yaitu tidak pernah melalaikan kewajibannya sebagai ummat Islam. Untuk diri sendiri yaitu menjaga kesehatan jasmani dan rohani. Untuk sesama manusia yaitu saling tolong menolong. Untuk lingkungan yaitu menjaga kelestarian alam. Untuk perasaan yaitu menjaga tingkah laku keseharian dan senang dinasehati. Untuk perkataan dan perbuatan yaitu menjaga mulut atau lidah dari kata-kata yang tidak sopan. Untuk budaya yaitu saling sapah dan menghargai yang lebih tua. Untuk adat dan istiadat yaitu menjaga nama baik keluarga, menjaga siri' napacce, sipakatau, sipaka inga' dan sipakalabbiri'.

Hal yang sangat penting ditegaskan adalah kedisiplinan santri, baik dari segi waktunya dari segi ibadahnya dan kehidupan sehari-harinya, membiasakan mengulang-ulang pembelajaran yang diberikan, memberikan motivasi yang nyata, membekali keimanan dan ketakwaan sehingga santri tetap menghargai dan mempertahankan prestasinya, baik di dalam pondok maupun di luar lingkungan Pondok Pesantren An-Nurîyah Bonto Cini' Kabupaten Jeneponto.

Inti dari implementasi pendidikan karakter adalah harus saling melibatkan diri antara ustadz dan santri pada ruang lingkup pembelajaran dan pemberian motivasi untuk memberi semangat berlajar (Marzuki, 2015: 35).

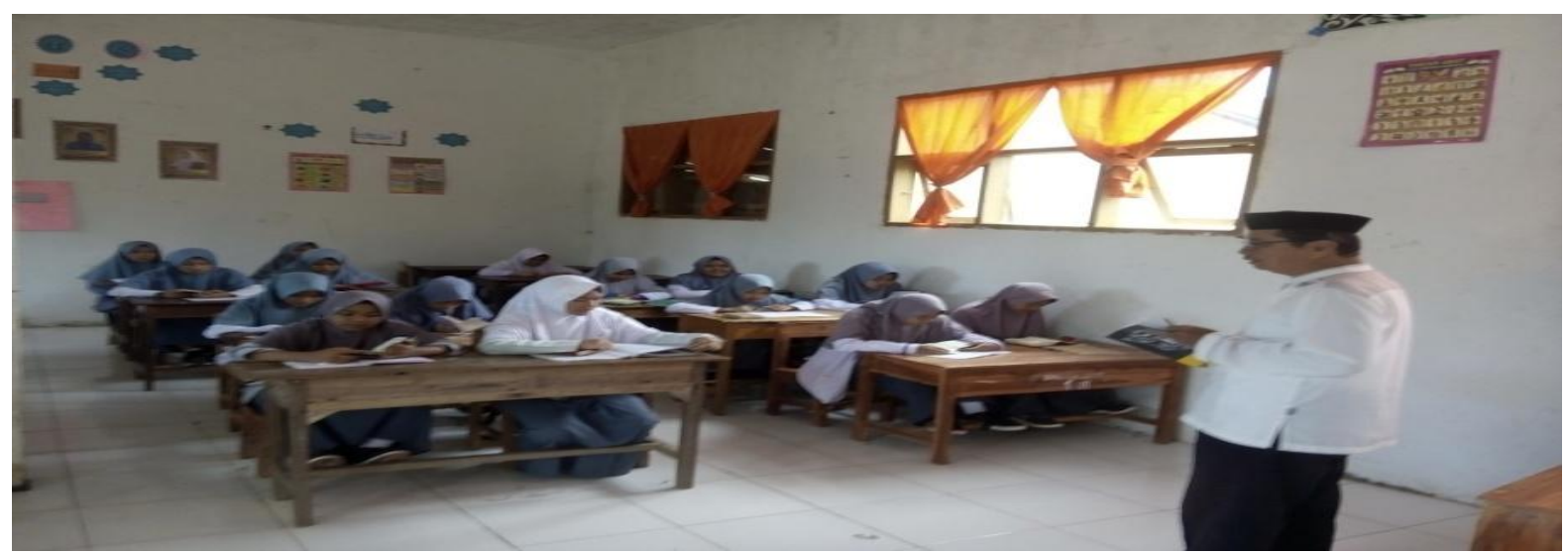

Dokumentasi proses pembelajaran santriwati di Kelas X MIA 1. di Pondok Pesantren An-Nurîyah Bonto Cini' Kabupaten Jeneponto, Provinsi Sulawesi Selatan. 


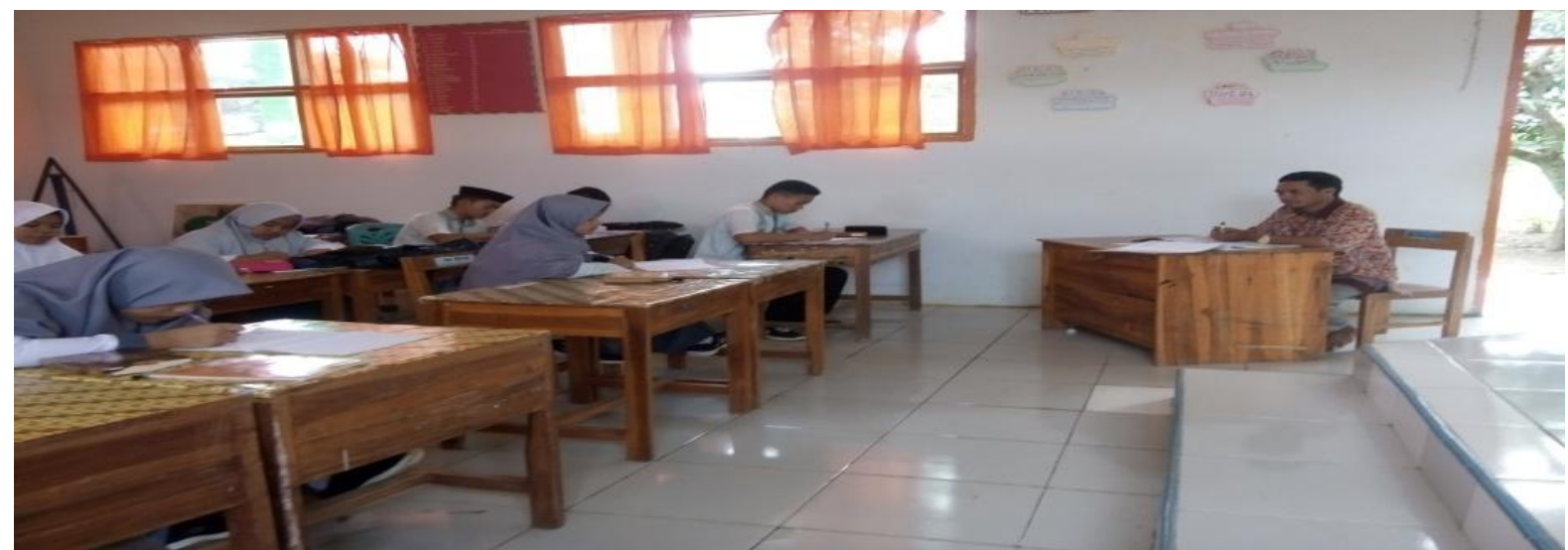

Dokumentasi proses pembelajaran santri dan santriwati di Kelas XII IIS, di Pondok Pesantren An-Nurîyah Bonto Cini' Kabupaten Jeneponto, Provinsi Sulawesi Selatan.

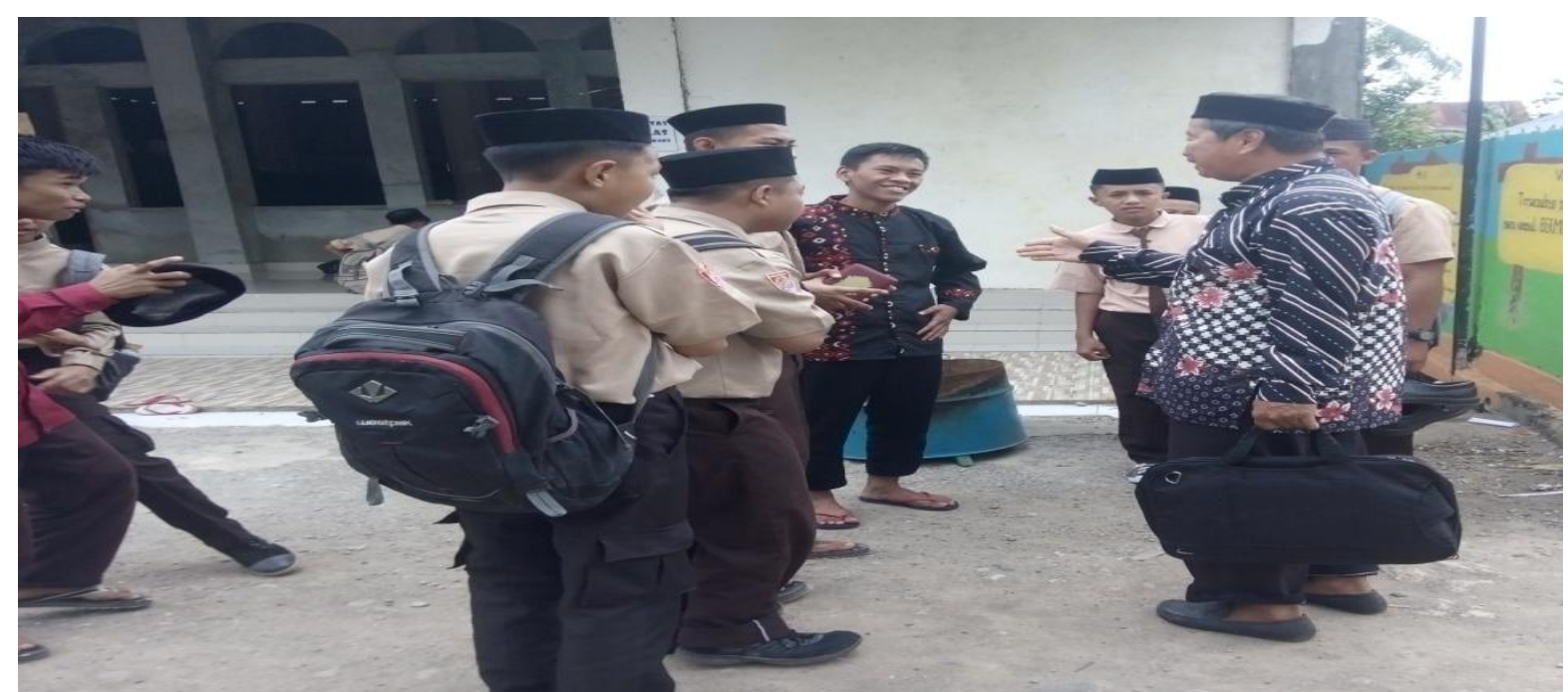

Dokumentasi Ustadz sedang memberi nasehat kepada santri di lingkungan Pondok Pesantren An-Nurîyah Bonto Cini' Kabupaten Jeneponto, Provinsi Sulawesi Selatan.

\section{Faktor Pendukung dan Penghambat} pada Implementasi Pendidikan Karakter di Pondok Pesantren AnNurîyah Bonto Cini' Kabupaten Jeneponto Provinsi Sulawesi Selatan.

Faktor pendukung yang utama pada implementasi pendidikan karakter di Pondok Pesantren An-Nurîyah Bonto Cini' yaitu: 1). Ada ustadz dan ustazah yang mengontrol setiap kegiatan santri yang sedang berlangsung; 2). Pembina selama 24 jam bersama dengan santri untuk memberi nasehat-nasehat tentang keagamaan dan pendidikan karakter; 3). Ketaatan santri dalam menekuni aturan yang ada di Pondok Pesantren AnNurîyah Bonto Cini' Kabupaten Jeneponto Provinsi Sulawesi Selatan serta tidak berani melanggar aturan tersebut secara signifikan dan selalu giat untuk belajar.

Faktor penghambat pada implementasi pendidikan karakter di Pondok Pesantren An-Nurîyah Bonto Cini' Provinsi Sulawesi Selatan yaitu: 1). Pengaruh dari dalam pondok tu sendiri, artinya dari kalangan para santri yang bekerja sama untuk tidak menaati peraturan yang ada di Pondok Pesantren An-Nurîyah Bonto Cini' Provinsi Sulawesi Selatan; 2). Pengaruh dari luar lingkungan Pondok Pesantren yaitu seperti virus-virus yang dapat memengaruhi santri untuk berani bolos, tidak pemperhatikan pembelajaran, tidak taat terhadap peraturan pondok dan berani melawan ustadz dan ustazahnya disebabkan karena adanya pengaruh 
pergaulan bebas dari luar pondok pesantren tersebut; 3). Lokasi Pondok Pesantren An-Nurîyah Bonto Cini' belum di pagar secara menyeluruh; 4) Mencobacoba untuk bolos, melawan ustadznya, tidak menataati aturan pondok, merokok di dalam area pondok, mencuri dan lainlain sebagainya; 5). Tidak ada perhatian orang tua mengenai tentang situasi dan kondisi anaknya yang berada di pondok pesantren tersebut, sehingga seorang anak tidak merasakan kasih sayang lebih dari seorang ibu dan ayahnya.

\section{Gambaran Karakter Santri di Pondok Pesantren An-Nurîyah Bonto Cini' Kabupaten Jeneponto Provinsi Sulawesi Selatan.}

Santri dan santriwati taat beribadah, bermasyarakat, bekerja sama, kehidupan sosialnya nampak, tawadhu, dan cinta terhadap lingkungan. Santri dan santriwati tidak ada yang melanggar secara signifikan, santri merasa temotivasi saat berdiskusi dengan para ustadz dan ustazahnya mengenai tentang hal yang bernuangsa ilmu agama dan ilmu umum, sopan dan santun dalam bercengkrama, saling menasehati kepada kebaikan, saling menghargai. Selanjutnya gambaran karakter santri pada implementasi pendidikan karakter di Pondok Pesantren An-Nurîyah Bonto Cini' Kabupaten Jeneponto yaitu santri dan santriwati tidak lagi dipaksakan untuk melakukan ibadah, bahasa sehari-harinya sudah baik, kegiatan sehari-harinya sudah efektif, kesehatan, dan keselamatan santri dan santriwati dalam kehidupan sehari-harinya dapat diperhatikan sendiri. Hal ini dikarenakan santri dapat mengimplementasikan pendidikan karakter dengan baik di lingkungan pondok pesantren.

Implikasi dari pendidikan karakter di dalam Pondok Pesantren An-Nurîyah Bonto Cini' yang dapat dilihat pada diri santri melalui: 1) Implementasi sikap santri yaitu kebiasaan santri untuk melaksanakan shalat sunnah duhah secara berjamaah di Masjîd, kebiasaan santri berpuasa setiap hari senin dan kamis, dan memperhatikan tingkat keseriusan dalam mengikuti proses pembelajaran, 2) Implementasi pendidikan karakater yang ditanamkan di Pondok Pesantren An-Nurîyah Bonto Cini' ini adalah melalui kegiatan pembiasaan yang baik, melauli kegiatan penanaman moral yang baik, dengan cara mengajar secara langsung santri tersebut untuk melakukan nilai-nilai religius tersebut, penanaman nilai-nilai religius ini bukan hanya santri dan santriwati yang harus memilikinya akan tetapi ustadz dan ustazahnya juga yang wajib memilikinya.

\section{Pembahasan Penelitian}

\section{Implementasi Pendidikan Karakter} di Pondok Pesantren An-Nurîyah Bonto Cini' Kabupaten Jeneponto Provinsi Sulawesi Selatan.

\section{Pondok Pesantren An-Nurîyah} Bonto Cini' Kabupaten Jeneponto merupakan salah satu pondok pesantren modern karena memadukan kurikulum agama dan kurikulum Pendidikan Nasional 2013. Nilai-nilai karakter yang ditanamkan di lingkungan Pondok Pesantren An-Nurîyah Bonto Cini' Kabupaten Jeneponto meliputi: a) nilai karakter hubungannya dengan Tuhan meliputi keimanan, ketakwaan, dan keikhlsan; b) nilai karakter hubungannya dengan diri sendiri meliputi kejujuran, tanggung jawab, kemandirian, kerja keras, disiplin, percaya diri, kreatif, dan ingin tahu; c) nilai karakter hubungannya dengan sesama yaitu patuh kepada peraturan, kerja sama, dan sopan santun; d) nilai karakter hubungannya dengan lingkungan yaitu peduli sosial dan cinta lingkungan; e) nilai karakter hubungannya dengan budaya adat dan istiâdat ialah menghargai keberagaman pemahaman. Nilai-nilai karakter ini kemudian implementasikan dalam pembentukan karakter melalui kegiatankegiatan berikut: 


\section{Tabel}

Hasil Implementasi Nilai Pendidikan Karakter di Pondok Pesantren An-Nurîyah Bonto Cini' Kabupaten Jeneponto.

\begin{tabular}{|c|c|c|}
\hline No. & Nilai Karakter & Indikator Karakter \\
\hline & Karakter religius & $\begin{array}{l}\text { Tidak melalaikan kewajiban seorang santri untuk } \\
\text { beribadah kepada Allah swt., secara berjamaah. Baik } \\
\text { melaksanakan ibadah wajib maupun ibadah sunnah } \\
\text { lainnya. Dan memperbaiki hubungan kepada sesama } \\
\text { manusia. }\end{array}$ \\
\hline 2. & $\begin{array}{l}\text { Nilai karakter } \\
\text { kemandirian }\end{array}$ & $\begin{array}{l}\text { Tidak lagi bergantung kepada orang tua dalam hal } \\
\text { berpakaian, makan cuci pakaian, cuci pirin, menjaga } \\
\text { kesehatan, rajin belajara seta taat terhadap aturan } \\
\text { yang berlaku di Pondok Pesantren tersebut. }\end{array}$ \\
\hline 3. & $\begin{array}{l}\text { Nilai karakter } \\
\text { kejujuran }\end{array}$ & $\begin{array}{l}\text { Berbuat baik tidak hanya memberi uang kepada } \\
\text { sesama manusia akan tetapi menanamkan sifat } \\
\text { kejujuran dalam hidup ini itu sangat besar } \\
\text { pengaruhnya untuk masa depan seorang santri. Sifat } \\
\text { kejujuran ini akan membahagiankan terhadap } \\
\text { pemiliknya. }\end{array}$ \\
\hline 4. & $\begin{array}{l}\text { Nilai karakter } \\
\text { kedisiplinan }\end{array}$ & $\begin{array}{l}\text { Kedisiplinan akan membuat santri merasa nyaman } \\
\text { dalam menghadapi setiap apa yang akan dilakukan } \\
\text { karena sifap kedisiplinan ini akan menjadi tolak ukur } \\
\text { untuk melakukan hal-hal yang kurang bermanfaat. }\end{array}$ \\
\hline 5. & $\begin{array}{l}\text { Nilai karakter kerja } \\
\text { keras }\end{array}$ & $\begin{array}{l}\text { Kerja keras adalah sesuatu yang sangat mutlak untuk } \\
\text { diimplementasikan dalam kehidupan setiap santri } \\
\text { lebih luasnya lagi untuk semua manusia karena tidak } \\
\text { ada hasil yang maksimal tanpa adanya kerja keras. }\end{array}$ \\
\hline 6. & $\begin{array}{l}\text { Nilai karakter } \\
\text { kepedulian antar } \\
\text { sesama manusia }\end{array}$ & $\begin{array}{l}\text { Santri yang baik adalah santri yang memeiliki } \\
\text { jaringan yang luas untuk mendapatkan informasi ang } \\
\text { baru, karena seseorang santri akan jenius ketika } \\
\text { santri tersebut mampu menguasai informasi dan } \\
\text { membagikan informasi tersebut kepada teman - } \\
\text { temanya yang lain. }\end{array}$ \\
\hline 7. & $\begin{array}{l}\text { Nilai karakter } \\
\text { kepedulian terhadap } \\
\text { lingkungan }\end{array}$ & $\begin{array}{l}\text { Memperbaiki lingkungan seirama dengan } \\
\text { memperbaiki kesehatan santri itu sendiri, lingkungan } \\
\text { yang sehat akan menghasilkan buah yang sehat dan } \\
\text { segar. Berdasarkan hal inilah lingkungan sangat } \\
\text { penting untuk diperhatikan. }\end{array}$ \\
\hline 8. & $\begin{array}{l}\text { Nilai karakter yang } \\
\text { kreatif }\end{array}$ & $\begin{array}{l}\text { Santri dapat mengambil beberapa pelajaran yang } \\
\text { daat dikembangkan dimasa depannya seperti halnya } \\
\text { mengembangkan bakat hafalannya, bakat, } \\
\text { dakwahnya, bakat lukisan kaligrafinya bakat } \\
\text { beladirinya dan lain-lain sebagainya. }\end{array}$ \\
\hline 9. & $\begin{array}{l}\text { Nilai karakter } \\
\text { toleransi }\end{array}$ & $\begin{array}{l}\text { Menghargai perbedaan itu adalah indah karena di } \\
\text { dunia ini tidak ada satu orangpun yang sama persis } \\
\text { baik dari bentuknya sampai kepada perilakunya, } \\
\text { berdasarkan hal inilah toleransi ini urgen untuk } \\
\text { diimplementasikan kedalam kehidupan setiap santri. }\end{array}$ \\
\hline
\end{tabular}




\begin{tabular}{|c|c|c|}
\hline 10. & $\begin{array}{l}\text { Nilai karakter pandai } \\
\text { membaca }\end{array}$ & $\begin{array}{l}\text { Belajar dari hal-hal yang baru itu diperlukan } \\
\text { kegemaran seorang santri dalam membaca, baik } \\
\text { membaca buku, membaca koran, membaca sosmed, } \\
\text { membaca situasi dan kondisi dan membaca hal-hal } \\
\text { yang terjadi saat ini. Setelah membaca maka } \\
\text { implementasikan hal-hal yang } \\
\text { diimplementasikan dalam kehidupan. }\end{array}$ \\
\hline 11. & $\begin{array}{l}\text { Nilai karakter untuk } \\
\text { rasa ingin tahu }\end{array}$ & $\begin{array}{l}\text { Sikap penasaran santri akan membuat santri itu } \\
\text { berusaha untuk mendapatkan rasa penasarannya } \\
\text { tersebut, akan tetapi sikap penasaran tersebut adalah } \\
\text { penasaran untuk mengetahui pelajaran yang belum } \\
\text { dipahami secara beik, maka santri tersebut selalu } \\
\text { penasaran untuk mencari tau dari hal-hal yang belum } \\
\text { diketahuinya. }\end{array}$ \\
\hline 12. & $\begin{array}{l}\text { Nilai karakter } \\
\text { bersahabat }\end{array}$ & $\begin{array}{l}\text { Karakter ini santri tidak dapat berkembang dengan } \\
\text { baik tanpa memiliki persahabatan yang baik pula } \\
\text { karena persahabatan inilah akan mendapatkan } \\
\text { pelajaran yang sesungguhnya seprti halnya } \\
\text { mengetahui rasa dari pahit manisnya kehidupan } \\
\text { bersama dengan sahabat. }\end{array}$ \\
\hline 13. & $\begin{array}{l}\text { Nilai karakter untuk } \\
\text { beranggung jawab }\end{array}$ & $\begin{array}{l}\text { Sikap tanggung jawab adalah sikap yang sngat } \\
\text { dicintai oleh Allah swt., karena dengan sikap } \\
\text { tersebutlah yang mampu mengimplementasikan } \\
\text { nilai-nilai pendidika karakter dengan baik. }\end{array}$ \\
\hline
\end{tabular}

Berdasarkan nilai-nilai karakter tersebut diperuntukkan kepada santri di Pondok Pesantren An-Nurîyah Bonto Cini' Kabupaten Jeneponto karena nilai-nilai tersebut digunakan oleh santri sebagai bekal dalam kehidupan sehari-harinya baik di dalam pondok pesantren maupun di luar pondok pesantren. Nilai-nilai karakter yang lain juga diterapkan di pondok pesantren adalah karakter kemandirian, tanggung jawab, kerja keras, percaya diri, kreatif, kerja sama, sopan santun, dan lain sebagainya. Sosok santri harus mencerminkan perilaku yang positif di masyarakat (Yaumi, 2014: 75).

Kegiatan ekstrakulikuler juga dimanfaatkan untuk menumbuhkan implementasi pendidikan karakter santri dan untuk mengembangkan karakterkarakter para santri. Ekstrakulikuler wajib di Pondok Pesantren An-Nurîyah Bonto Cini' Kabupaten Jeneponto adalah menghafal, pramuka, qasîdah, tarung derajat, takraw, dan volly, sedangkan ekstrakulikuler pilihan meliputi seni kaligrâfi, belajar bahasa Inggris, Arab, Jepang, Prancis, dan Mandarin. Karakterkarakter yang dikembangkan melalui kegiatan ekstrakulikuler ini diantaranya adalah karakter kepemimpinan, kemandirian, tanggung jawab, peduli lingkungan, dan peduli terhadap sesama, peduli sosial, kerja sama, kerja keras, cinta lingkungan, keberanian, cerdas dan kreativitas dalam diri santri. Selain itu ekstrakulikuler yang juga digunakan pula untuk mengembangkan karakter religius seperti dalam ekstrakulikuler Tarung Derajat yang berupa ketaatan dan kepatuhan kepada Allah swt., disiplin, mematuhi peraturan yang sudah ada, dan tidak pelit ilmu (Shihab, 2009: 217).

$$
\text { Berdasarkan hasil penelitian }
$$
menunjukan bahwa Pondok Pesantren An-Nurîyah Bonto Cini' Kabupaten Jeneponto sebagai pondok pesantren 
modern telah melaksanakan pendidikan karakter. Pendidikan karakter yang dilakukan di pondok pesantren bertujuan untuk membentuk karakter baik pada diri santri, agar santri mempunyai perilaku dan kebiasaan yang baik ketika berada di masyarakat (Wibowo, 2012: 33).

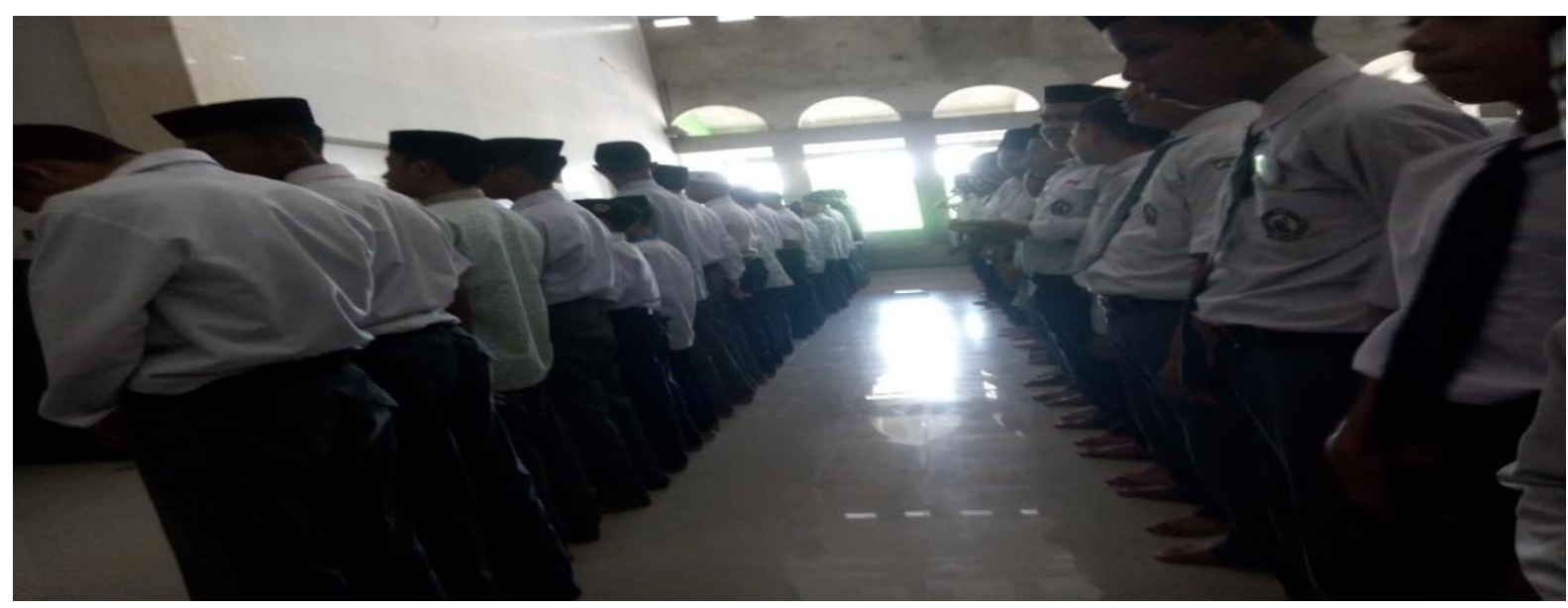

Dokumentasi Santri sedang Shalat Sunnah Duhâh di Masjîd Pondok Pesantren An-Nurîyah Bonto Cini' Kabupaten Jeneponto.

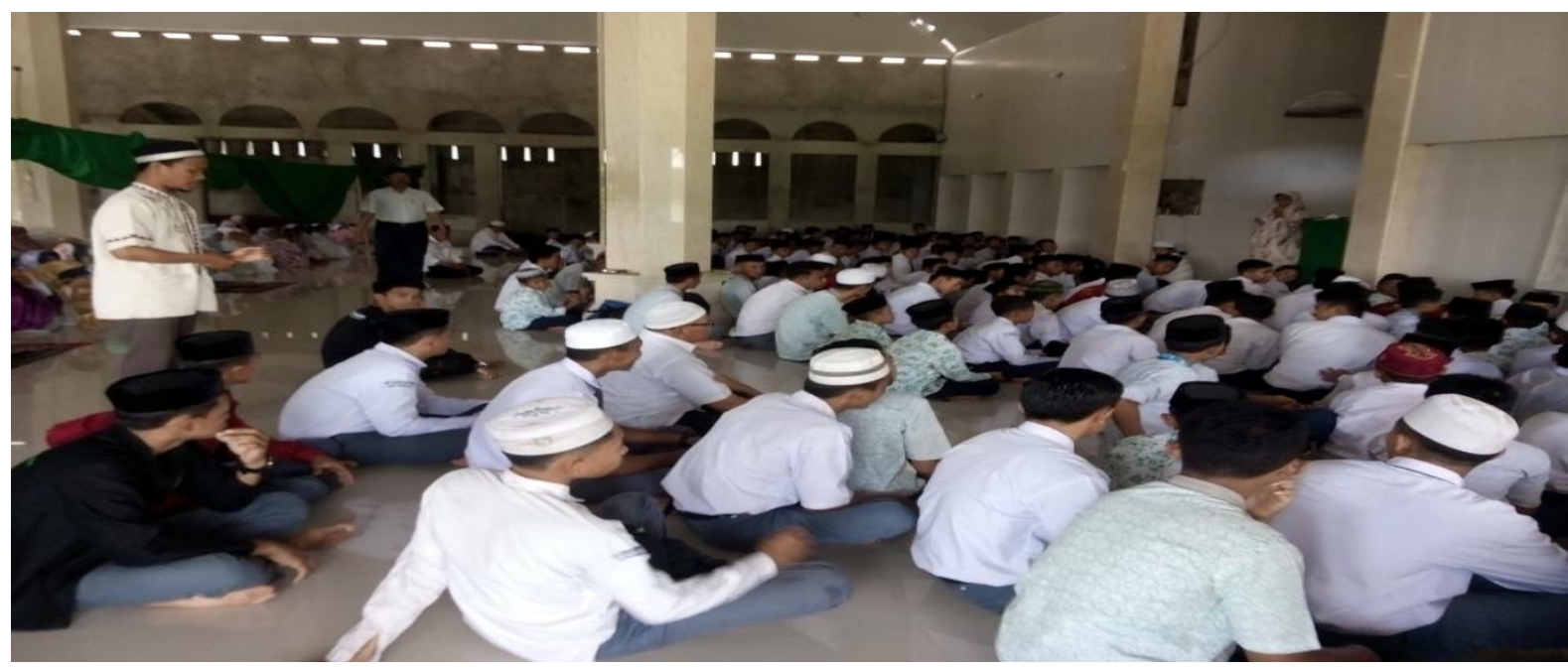

Dokumentasi Santri dan Santriwati Setelah Selesai Melaksanakan Shalat Dhûhur berjamâah di Masjîd Pondok Pesantren An-Nurîyah Bonto Cini' Kabupaten Jeneponto.

Metode yang digunakan dalam pendidikan karakter di Pondok Pesantren An-Nurîyah Bonto Cini' Kabupaten, yaitu:

Metode pembiasaan. Para santri melaksanakan secara rutin kegiatan yang telah terjadwal tersebut. Kelebihan metode pembiasaan ini ialah para santri akan terbiasa melakukan hal-hal yang positif dengan sendirinya, sedangkan kelemahannya adalah memerlukan pengawasan khusus oleh ustadz agar kebiasaan-kebiasaan yang dilakukan para santri tidak menyimpang (Sutirman, 2016: 91).
Metode pemberian nasehat Abdurrahman al-Nahlâwi sebagaimana dikutip oleh Hery Noer Aly mengatakan bahwa yang dimaksud dengan nasihat adalah penjelasan kebenaran dan kemaslahatan dengan tujuan menghindarkan orang yang dinasihati dari bahaya serta menunjukkan-Nya ke jalan yang mendatangkan kebahagiaan dan manfaat (Haedar, 2013: 92). Pemberian nasehat di pondok pesantren di berikan oleh ustadz melalui beberapa cara, yaitu: a) secara terbuka pemberian nasehat diberikan kepada santri dalam 
forum yang luas seperti setelah sholat berjamâah, dalam kegiatan evaluasi malam maupun di dalam kelas, b) pemberian nasehat secara spontan diberikan oleh ustadz pada saat bercanda gurau dengan santri, pada saat berjalan dan lain-lain; c) pemberian nasehat secara tertutup atau rahasia apabila santri mempunyai masalah dan memerlukan solusi dari permasalahannya secara personal (Wibobo, 2012: 34).

Metode keteladanan diberikan oleh pengelola dan pendidik di Pondok Pesantren An-Nuriyah Bonto Cini' Kabupaten Jeneponto. Keteladanan dicontohkan dalam perilaku dan sikap sehari-hari. Ustadz/ustazah berperilaku baik terhadap sesama ustadz atau ustadzah maupun kepada santri. Dalam hal berpakaian, ustadz atau ustadzah selalu berpakaian rapi, menggunakan bahasa yang baik dan benar sehingga Ustadz/ustazah dapat memberi contoh kepada santri untuk menggunakan bahasa yang baik dan benar serta penampilan yang rapi yang telah ditentukan oleh peraturan pondok pesantren (Rama, 2010: 59).

Metode praktik diberikan kepada santri dengan cara santri diikutsertakan di lingkungan masyarakat. Metode praktik di Pondok Pesantren An-Nurîyah Bonto Cini' Kabupaten Jeneponto yakni melalui kegiatan dakwah santri, jadwal baca khotbah santri di luar pesantren, dan amal bakti santri. (Khan, 2010: 19).

Berdasarkan beberapa metode yang diuraikan, metode yang mudah diterima oleh santri dan efektif diterapkan ialah metode pembiasaan, metode keteladanan dan metode hukuman. Pembiasaan dilakukan secara rutin oleh santri maka santri akan terbiasa dengan hal-hal yang positif. Keteladanan yang ditunjukan oleh ustadz dan ustazah membuat santri untuk meniru karakter yang dimiliki ustadz dan ustazah tersebut. Selain itu, pemberian hukuman akan membuat santri takut untuk melakukan pelanggaran sehingga santri berusaha untuk melakukan perilaku yang baik (Muhaimin, 2010: 223).

2. Faktor pendukung dan penghambat pada implementasi pendidikan karakter di Pondok Pesantren AnNurîyah Bonto Cini' Kabupaten Jeneponto Provinsi Sulawesi Selatan.

Proses pembentukan karakter pada diri santri adalah sangat erat hubungannya dengan faktor intern (individu) para santri itu sendiri dan juga faktor ekstern (lingkungan) baik dalam masyarakat, rumah, pondok pesantren, dan sebagainya. Faktor intern (individu manusia) yang telah diciptakan oleh Tuhan sebagai makhluk yang telah dibekali dengan daya pikir cipta dan kemauan atau secara singkat dimaknai sebagai fitrah manusia yang memiliki karakteristik yang berbeda dengan yang lainnya, merupakan salah satu faktor yang menetukan pembentukan karakter tersebut. Faktor ekstern (lingkungan) merupakan faktor yang dapat mempengaruhi pembentukan dan perkembangan perilaku individu baik lingkungan fisik maupun sosiologi pada santri, sehingga dapat menciptakan perubahan karakteristik. (Nasution, 2010: 11).

Faktor intern (individu manusia) yang telah diciptakan oleh Tuhan sebagai makhluk yang telah dibekali dengan daya pikir cipta, dan kemauan atau secara singkat dimaknai sebagai fitrah manusia yang memiliki karakteristik yang berbeda dengan yang lainnya, merupakan salah satu faktor yang menetukan pembentukan karakter tersebut. Faktor ekstern (lingkungan) merupakan faktor yang dapat memengaruhi pembentukan dan perkembangan perilaku individu baik lingkungan fisik maupun sosiologi pada santri, sehingga dapat menciptakan perubahan karakteristik.

Selain itu, ada pula faktor-faktor pendukung dan penghambat dalam 
perkembangan Pondok Pesantren AnNurîyah Bonto Cini'. Faktor pendukung internal berkembanganya Pondok Pesantren An-Nuriyah Bonto Cini', adalah: a. Adanya kinerja pengurus yang baik. Menurut Sunarto dan Agung Hartanto (1999: 17) selain pengurus, kemampuan seorang tenaga pendidik pula terhitung sangat besar dalam perkembangan lembaga pendidikan karakter dan keagamaan, serta adanya tenaga pendidikan yang mempuni, b. Peran aktif pendiri Pondok Pesantren An-Nurîyah AG. H. M. Yahya Ahmad, Lc., M. Pd. yang merupakan pendiri Pondok Pesantren An-Nurîyah Bonto Cini' dari awal pendirian hingga sekarang, c. Adanya ustadz/ustazah yang baik dan bijak yang menjadi panutan dalam kehidupan santri, d. Proses pembelajaran yang berkualitas yang berjalan sesuai dengan kurikulum agama yang ditetapkan oleh pondok pesantren dan juga kurikulum 2013, e. Dukungan dari keluarga besar AG. H. M. Yahya Ahmad, Lc., M. Pd., yang merupakan faktor pendukung utama dalam berdirinya Pondok Pesantren AnNuriyah Bonto Cini' Kabupaten Jeneponto, f. Sarana dan prasarana yang memadai.

Faktor pendukung eksternal berkembanganya Pondok Pesantren AnNurîyah Bonto Cini', antara lain: a. Dukungan pemerintah Desa Bonto Cini' dengan memberikan dukungan berupa penataan lokasi yang strategis kepada pihak pengelola pondok pesantren ini (AG. H. M. Yahya Ahmad, Lc., M. Pd.), b. Dukungan positif tokoh masyarakat dan warga setempat Desa Bonto Cini', dengan memberikan restu dan sambutan yang baik untuk pembangunan Pondok Pesantren An-Nurîyah Bonto Cini'. Hal ini dibuktikan dengan adanya tiap kegiatankegiatan dalam pesantren masyarakat ikut membantu dalam setiap acara di Pondok Pesantren An-Nurîyah Bonto Cini', c. Letak pesantren yang strategis, Pondok Pesantren An-Nurîyah Bonto Cini' terletak di tengah-tengah desa Bonto Cini' Kecamatan Batang Kabupaten Jeneponto, sehingga dengan letak yang strategis ini, membuat pesantren menjadi ramai dan muda terakses bagi tamu atau wali santri yang ingin mendatangi anaknya masingmasing.

Faktor penghambat pada implementasi pendidikan karakter di Pondok Pesantren An-Nurîyah Bonto Cini', yaitu: Faktor penghambat internal yaitu: a. Pola perilaku santri dan santriwati yang terkadang sulit diatur dan banyaknya santri yang bolos, b. Sarana dan prasarana yang tidak terjaga, seperti kursi dan meja yang tidak teratur serta tembok dicoret-coret, c. Kurangnya pendanaan karena kurang perhatian pemeritah terhadap pondok pesantren tersebut, d. Adanya kebijakan pesantren yang terkadang dinilai sepihak dan jarang bisa diterima oleh masyarakat meskipun demi kebaikan pesantren, sehingga dapat mempengaruhi pola pikir masyarakat untuk meninggalkan dunia pesantren (Amin dan Sutirman, 2016: 257).

2. Faktor Penghambat Eksternal

Adapun faktor penghambat eksternal di Pondok Pesantren AnNurîyah Bonto Cini' adalah sebagai berikut:

a. Kurangnya minat masyarakat pada pesantren sehingga banyak dari orang tua lebih senang menyekolahkan anakanak mereka di pendidikan yang berbasis umum,

b. Masyarakat kurang memahami seluk beluk pesantren sehingga para pengasuh dan pengurus pesantren memberikan motivasi agar dapat menunjang masyarakat dengan lebih jauh lagi, dapat memberikan program pendidikan agama Islam dengan baik dan unik sehingga santri merasa penasaran dan ingin tinggal di Asrama,

c. Kurangnya sarana penunjang baik dari segi transportasi maupun dari segi infrastuktur (Sutrisno, 2017: 523). 
3. Gambaran karakter santri di Pondok Pesantren An-Nurîyah Bonto Cini' Kabupaten Jeneponto, Provinsi Sulawesi Selatan.

Gambaran karakter santri di pondok pesantren An-Nurîyah Bonto Cini', yaitu: Pelaksanaan nilai karakter religius santri yaitu tidak melalaikan kewajiban seorang santri untuk beribadah kepada Allah swt., secara berjamâah, dan memperbaiki hubungan kepada sesama manusia; Nilai kemandirian berbuat baik tidak hanya memberi uang kepada sesama manusia akan tetapi menanamkan sifat kejujuran dalam hidup ini itu sangat besar pengaruhnya untuk masa depan seorang santri, Sifat kejujuran ini akan membahagiankan terhadap pemiliknya, Kedisiplinan akan membuat santri merasa nyaman dalam menghadapi setiap apa yang akan dilakukan, Kerja keras sangat mutlak untuk diimplementasikan dalam kehidupan setiap santri, Peduli sosial santri yang baik adalah santri yang memiliki jaringan yang luas untuk mendapatkan informasi yang baru, dan membagikan informasi tersebut kepada teman-temanya, Peduli lingkungan untuk memperbaiki lingkungan yang sehat dan segar yang akan mendatangkan manfaat untuk alam itu sendiri, Kreatif santri untuk mengambil beberapa pelajaran yang dapat dikembangkan dimasa depannya, Nilai toleransi terhadap menghargai perbedaan itu adalah indah karena berlandaskan sunnah tullah, Gemar membaca, baik membaca buku pelajaran, membaca koran, membaca sosmed, membaca situasi dan kondisi dan membaca hal-hal yang terjadi saat ini, Rasa ingin tahu membuat santri giat untuk mengetahui pelajaran yang belum dipahami secara baik, maka santri tersebut selalu penasaran untuk mencari tau dari hal-hal yang belum diketahuinya, Bersahabat/komunikatif karakter ini santri tidak dapat berkembang dengan baik tanpa memiliki persahabatan atau jaringan yang luas, Tanggung jawab adalah sikap yang sangat dicintai oleh Allah swt., karena sikap inilah yang mampu mengimplementasikan nilai-nilai pendidika karakter dengan baik (Setiawati, 2017: 348-349).

\section{PENUTUP}

Berdasarkan urain di atas dapat diambil kesimpulan bahwa implementasi pendidikan karakter di pondok pesantren An-Nurîyah Bonto Cini' di dalam kelas dan luar kelas, meliputi penanaman nilainilai religius, kemandirian, tawâdhu, jujur, menghargai prestasi, mencintai lingkungan, peduli sosial, kreatif, gemar membaca, toleransi, bertanggung jawab, kedisiplinan, kerja sama, kerja keras, dan kreativitas.

Kemudian untuk mewujudkan nilainilai karakter tersebut keteladanan pendidik sangat menentukan. Oleh karena itu pendidik diharapkan mampu meningkatkan fungsinya dalam hal mendidik, membimbing, mengarahkan, melatih, dan memotivasi supaya para santri terbiasa berperilaku dengan nilainilai karakrter yang baik.

Berikutnya, kondisi santri Pondok Pesantren An-Nurîyah Bonto Cini' sangat baik, di sana tidak ditemukan pelanggaran yang signifikan, justru santri di pondok ini dibina untuk mampu dan berupaya dalam meningkatkan proses pembelajaran, hal itu dilakukan untuk mewujudkan generasi berkarakter, berintegritas, dan tetap unggul sangat.[]

\section{DAFTAR RUJUKAN}

Amin, Moh. dan Sutirman. "'Pelaksanaan Pendidikan Karakter Peserta Didik di SMK Negeri 1 Wonosari." Jurnal Pendidikan Administrasi PerkantoranS1 5.3 (2016): 249-259.

Bawani, Imam. Tradisionalisme dalam Tradisi Islam, Surabaya: al-Ikhlas, 2009.

Damopolii, Muljono. Pembaruan Pendidikan Islam di Makassar (Studi Kasus Pesantren Modern Pendidikan 
Al-Qur'ân IMMIM Tamalanrea Makassar), Disertasi, Jakarta: Program Pascasarjana UIN Syarif Hidâyatullah, 2011.

Hurairah. Pengorganisasian dan Pengembangan Masyarakat dan Strategi Pembangunan yang Berbasis Kerakyatan, Bandung: Humaniara, 2009.

Kamus Pusat Bahasa. Kamus Besar Bahasa Indonesia, Cet. II; Jakarta: Balai Pustaka, 2014.

Kementerian Agama RI. Mushâf al-Qur'ân Terjemah, Jakarta: Pena Pundi Aksara, 2014.

Khan, Yahya. Pendidikan Karakter Berbasis Potensi Diri, Yogyakarta: Pelangi Publishing, 2010.

Marzuki. Pendidikan Karakter Islam, Cet. II; Jakarta: Paragonatama Jaya, 2015.

Muhaimin. Paradigma Pendidikan Islam: Upaya Mengefektifkan Pendidikan Agama Islam di Sekolah, Bandung: PT. Remaja Rosdakarya, 2010.

Nahrawi, Amiruddin. Pembaharuan Pendidikan Pesantren, Yogyakarta: Gama Media, 2010.

Nasir, Haedar. Pendidikan Karakter, Berbasis Agama dan Budâya, Yogyakarta: Multi Presindo, 2013.

Nasution, S. Sosiologi Pendidikan, Jakarta: Bumi Aksara, 2010.

Rama, Bahaking. Jejak Pembaharuan Pendidikan Pesantren, Jakarta: PT. Paradotama Wirangemilang, 2010.

Samani, Muchlas dan Hariyanto. Konsep Dan Model Pendidikan Karakter, Bandung: Remaja Rosdakarya, 2014.

Setiawati, Nanda Ayu. Pendidikan Karakter, Sebagai Pilar Pembentukan Karakter Bangsa: Prosiding Seminar Nasional Tahunan, Fakultas Ilmu Sosial Universitas Negeri Medan, 2017.

Shihab, M. Quraish. Mahkota Tuntunan Ilâhi, Tafsîr al-Misbah, Vol. I. Cet. II; Jakarta: Lentera Hati, 2009.
Sugiyono. Metode Penelitian Pendidikan: Pendekatan Kualitatif, dan Kuantitatif, $R \& D$, Bandung: Alfabeta, 2013.

Suharto, Babun. Dari Pesantren Untuk Umat: Reiventing Eksistensi Pesantren, di Era Globalisasi, Edisi: Pertama. Surabaya: Imtiyaz, 2011.

Sukmadinata, Syaodih. Metode Penelitian Pendidikan, Cet. III; Bandung: PT. Remaja Rosdakarya, 2009.

Sunarto dan Agung Hartanto. Perkembangan Peserta Didik, Jakarta: Rineka Cipta, 2009.

Sutrisno. "Implementasi Pendidikan Karakter di Pondok Pesantren Modern Muhammadîyah Boarding School (MBS) Yogyakarta". Jurnal Pendidikan Luar Sekolah, 2017.

Tanshzil, Sri Wahyuni. "Model Pembinaan Pendidikan Karakter pada Lingkungan Pondok Pesantren dalam Membangun Kemandirian dan Disiplin Santri: Sebuah Kajian Pengembangan Pendidikan Kewarganegaraan." Jurnal Penelitian Pendidikan, 2012.

Wibowo, Agus. Pendidikan Karakter: Strategi Membangun Karakter Bangsa, Yogyakarta: Pustaka Pelajar, 2012.

Yasmadi. Modernisasi Pesantren: Kritik Nurcholis Madjid Terhadap Pendidikan Islam Tradisional, Cet. II; Jakarta: Ciputat Press, 2009.

Yaumi, Muhammad. Pendidikan Karakter: Landasan Pilar dan Implementasi, Cet. I; Jakarta: Kharisma Putra Utama, 2014. 